\title{
Envisaging the alternatives : From knowledge of the powerful to powerful knowledge in history classrooms
}

\section{Puustinen, Mikko}

2021-01-02

Puustinen, M \& Khawaja , A 2021, ' Envisaging the alternatives : From knowledge of the powerful to powerful knowledge in history classrooms ' , Journal of Curriculum Studies, vol. 53 , no. 1 , pp. 16-31 . https://doi.org/10.1080/00220272.2019.1703273

http://hdl.handle.net/10138/330648

https://doi.org/10.1080/00220272.2019.1703273

acceptedVersion

Downloaded from Helda, University of Helsinki institutional repository.

This is an electronic reprint of the original article.

This reprint may differ from the original in pagination and typographic detail.

Please cite the original version. 
Envisaging the alternatives: From knowledge of the powerful to powerful knowledge in history classrooms 


\title{
Envisaging the alternatives: From knowledge of the powerful to powerful knowledge in history classrooms
}

\author{
Michael Young's ideas of powerful knowledge have gained considerable \\ attention in recent years. However, the pedagogical aspects of powerful \\ knowledge are less developed than its knowledge theorization. In this case study, \\ we explore pedagogical practices that could promote powerful knowledge in \\ school history. In so doing, we analyze teaching sessions conducted by two \\ teachers. The cases were selected from an observation study that focused on \\ historical literacy in Finnish schools. Our results indicate that promoting \\ powerful knowledge is possible in school history. We suggest that powerful \\ knowledge could be supported by teacher-led pedagogy that involves the \\ systematic use of historical texts, and that uses disciplinary concepts to re- \\ conceptualize everyday knowledge. We also propose that everyday knowledge in \\ history may differ from the definition by Young and Muller (2014). Hence, \\ teaching aims to unpack the (political) use of historical knowledge and narratives \\ that represent the knowledge of the powerful.
}

Keywords: historical literacy, historical thinking, history education, powerful knowledge

\section{Introduction}

'He who controls the past controls the future. He who controls the present controls the past.' George Orwell, Nineteen Eighty-Four.

A school subject is never a simple reduction of a discipline. Disciplinary knowledge is transformed to fit the educational purposes of teaching (Gericke, Hudson, Olin-Scheller, C. \& Stolare, 2018). History as a school subject is no exception. The origins of the subject are closely connected to the construction of nation states during the 19th century. In Orwell's dystopia, history was used for legitimizing the structures of power. The idea of powerful knowledge was developed by Michael Young (2009). For Young (2014c), powerful knowledge represents knowledge that is distinct from 
everyday knowledge, and that is systematic and specialized. Powerful knowledge makes it possible to predict, explain and envisage alternatives. The opposite of powerful knowledge is the knowledge of the powerful, which represents the knowledge of those who are in power (Muller \& Young, 2019)

To counter the Orwellian-like world of restricted perspectives, history teaching can offer unbeatable tools for citizens to live in a world where conflicting information and social media are challenging democratic societies. However, ever since Herodotus, history has been used to control the views of contemporaries. From the 19th century onwards, this was often done by narrating the history of the winners within a nationalistic frame. We call this view and the use of history the heritage approach (Lowenthal, 1998), while we use the term history to refer to the promotion of disciplinary history.

Many of the debates over how to construct history curricula seem to be connected to the heritage view of history teaching, with the struggle concerning whose heritage, narrative or interpretation should be transmitted. In this sense, the heritage view of history teaching seems to represent the power of the powerful in its pure form. In contrast, powerful historical knowledge makes it possible to go beyond the national narrative, to switch perspectives, make generalizations and think beyond particular contexts - something that shakes up heritage with a fixed narrative.

The discussion concerning powerful knowledge has often taken place at a theoretical level. The pedagogical aspects of powerful knowledge are less developed than its knowledge theorization (McPhail \& Rata, 2018). Thus, there is a call for further research on pedagogy that helps students to create powerful knowledge (Gericke et al., 2018; McPhail \& Rata, 2018). 
In order to describe the process whereby disciplinary knowledge is converted into teachers' decisions and actions, we use the concept of transformation. As suggested by Gericke and colleagues (2018), transformation refers to the process through which disciplinary knowledge is changed into what is taught and learned through various processes. Teaching is seen as intentional decisions and actions that nonetheless take place within the frame of societal (e.g. policies, national core curriculum, traditions, high-stakes testing) and institutional (school culture and resources) settings.

In this article, we focus on the classroom level by studying pedagogical practices that promote powerful knowledge in school history. The data for the present case study are drawn from a larger study, in which we observed historical literacy in Finnish schools. Counsell (2011), Harris and Reynolds (2018), and Harris and Ormond (2019) have studied history-teacher activity and curriculum decision-making within the framework of powerful knowledge. However, none of these studies include observation data.

We begin by examining powerful knowledge in the context of school history and by looking into the criteria for teaching disciplinary history. After describing our data, research methods and the context of our study, we analyze teaching sessions conducted by two teachers. Based on our data and history education research, we outline guidelines for pedagogy that would support powerful knowledge. These preliminary views could serve as a starting point for a more advanced discussion on how powerful historical knowledge could be implemented in classrooms.

\section{Historical literacy as a prerequisite for powerful knowledge}

Disciplines can be seen as communities of practice that have their own forms of norms and conventions that shape knowledge claims and argumentation (Lave \& Wenger, 1991; see also Goldman et al., 2016). In this sense, a discipline exists because of its 
epistemic structure (McPhail \& Rata, 2018). The above-mentioned stance leads to the idea that knowledge, knowledge production and literacy practices are inseparable (Fang \& Coatoam, 2013; Hynd-Shanahan, 2013).

Our research is grounded in the concept of historical literacy. As defined by Nokes (2010): 'historical literacy is the ability to glean appropriate information about the past from resources of many genres. It is the ability to engage in historical processes - to not simply possess knowledge, but to know how to build it. It is the ability to work with historical evidence in all of its genres.' We emphasize that merely reading historical texts without an in-depth grasp of the historical context is not synonymous with historical literacy. As Lee (2011) for example points out, historical literacy includes understanding the concept of evidence and other disciplinary concepts, as well as respect for the people in the past. History educators stress that historical literacy abilities are fundamentally different from other types of reading (Nokes, 2010; Wineburg, 1991, 2001; Vansledright, 2002). For instance, historians must be able to fill in any gaps in the evidence with reasonable inferences, view texts as evidence rather than as collections of facts, and see texts as extensions of individuals with their biases, perspectives, and personalities. In other words, disciplinary knowledge in history includes both substantive and procedural knowledge (VanSledright \& Limon, 2006).

Historical literacy is closely connected to historical thinking, which is a widely used but rather ambiguous concept. Some view historical literacy as a broad concept including nearly everything connected to history teaching (Maposa \& Wasserman, 2009). Others define historical literacy as the result of historical thinking (Seixas, 2006). We understand historical literacy not as a result but as an essential part of historical thinking. The epistemic basis of history is built on grasping the interpretative nature of the discipline. This foundation is the prerequisite for historical thinking. Disciplinary 
knowledge, in turn, is produced through historical thinking. Thus, our view seems to resonate with Ruth Sandwell's (2014) idea that historical thinking is visible in historians' ability to interpret historical evidence and create meaningful narratives.

The discipline of history has its own epistemology, in other words, a specific way to approach knowledge. In school history, however, the epistemology is often invisible to students, who are not made aware of the way in which historical knowledge is constructed. As Nokes (2010) notes, historians' interpretations of the past are often presented to the public through textbooks or historical documentaries. Hence, historical narratives may emerge as something distinct from the historical inquiry process.

Next, we briefly discuss how powerful knowledge has been defined in school history, drawing in particular on Bertram's (2019) theoretical considerations. First, powerful knowledge is specialized disciplinary knowledge that is specific to a particular discipline. Traditional school history often focuses on transmitting collective memory. Without disciplinary lenses, history is reduced to a list of facts, to 'events that happened'. As Young (2014a) points out, facts are needed, but by themselves they are not knowledge. The purpose of disciplinary school history is to develop learners' historical thinking (Levesque, 2008; Seixas \& Morton, 2013; Wineburg, 2001). On the other hand, historical thinking should not be perceived as skills in the general meaning, and cannot be developed without substantive knowledge. Therefore, powerful knowledge also includes both substantive and procedural knowledge.

Second, powerful knowledge is systematic - it forms a network of concepts that are systematically related to each other. Although history as a discipline does not aim for or promise an all-encompassing theory or explanations, it can provide tools for abstraction and generalization. For Bertram, (2019) time, namely chronology, is the main organizing principle of concepts. In addition, connections can be made by 
analyzing a substantive concept like 'revolution' in a different context and at a different time. Based on Haenen and Schrijnemaker's (2000) definition of generic, unique and universal substantive historical concepts, Bertram reasons that school history should focus on concepts that enable abstract thinking and generalizations. In this sense, universal historical concepts, such as civil war, estate, or revolution allow many more abstractions than general concepts like law and government, or unique historical concepts such as Stalinism or apartheid. Along with substantive concepts, second-order concepts are necessary in order to organize and build substantive knowledge. They are essential for separating powerful knowledge from a list of contents (Muller and Young, 2019).

Third, powerful knowledge is distinct from everyday knowledge. Everyday historical knowledge derives from historical culture and is maintained, for example, by popular culture, families, local communities and nation states (Bertram, 2019). Bertram notes that everyday history is close to learners in time and space. In order to form powerful knowledge, history teaching should duly aim far or high, helping students to go beyond local or national perspectives and contexts. In this sense, everyday knowledge about history seems to differ slightly from the everyday knowledge acquired through experience or practical activities as defined by Young and Muller (2014).

We conclude that grasping how historical knowledge is produced is essential for understanding historical knowledge. Further, this is at the heart of powerful knowledge because a single narrative might serve someone's interests but probably not everyone's.

\section{From the heritage approach to history}

In the light of the history wars that have taken place in many Western societies during past decades (Nash et al., 2000), Orwell's dystopian statement seems to capture the 
conflicting essence of school history: should it emphasize qualification, subjectification or socialization (Biesta, 2009). Of these domains, socialization, namely becoming a part of existing traditions, and subjectification, promoting criticality, seem to be in conflict. In the context of school history, the first can be defined as the heritage view of history teaching, while the latter encourages a more disciplinary approach (Cuban, 2016; Lowenthal, 1998). In addition, the public view that the purpose of school history should be to learn some basic facts leads to a single narrative approach. We argue that the position of history differs somewhat from other subjects because of the many socialization hopes assigned to it. Thus, the 19th-century origins of school history as a national narrative transmitter are still deeply rooted in school systems and especially in public views (Cuban, 2016; Nash et al., 2000; VanSledright, 2002).

The historical development of school history is linked to the curriculum Futures outlined by Young and Muller (2010), who characterize Future 1 as 'under-socialized' fixed sets of facts and, in contrast, Future 2 as 'over-socialized' in the sense that knowledge is reduced to depending on the knower. Future 1 seems to be unable to motivate students and offers irrelated facts instead of knowledge. However, according to Young and Muller (2010), the alternative, Future 2, has lost knowledge as well. Promoting generic skills and learning competences may lead to access to specialized knowledge disappearing. As a solution, they propose the Future 3 approach, which would be based on disciplinary knowledge and would produce powerful knowledge for learners.

In school history, Future 1 represents the retelling of national narratives. It is a history of the winners, in which interpretations are fixed: historical literacy is not supported. The dominant pedagogical practices support memorization. Future 2 is connected to the training of general skills or doing 'source work' without a historical 
frame. History can be seen as facts that are subordinated to general skills, and not as knowledge in and of itself. Due to the separation of substantive and procedural knowledge, historical literacy is not supported. Futures 1 and 2 leave many students blind to the political and social use of history, since they do not understand how historical interpretations are made and can be used for controlling present or possible futures. Both represent the knowledge of the powerful despite how different their approach may seem at first sight.

Muller and Young (2019) provide an old yet important notion stemming from Ryle (1945) about repeating facts without understanding their importance. At the other end of the continuum is history as opinions. Some of VanSledright's (2002) primary school pupils started to think that nothing could be trusted in history and argued that the historical accounts they were supposed to analyze were fake or purposefully mendacious. Both stances represent a misconception of history as a discipline and as a school subject.

Future 3, in turn, refers to disciplinary history and its conventions. A conclusion based only on the everyday experience or opinions of a learner is not historical knowledge. Even though 'truth' accessed through historical inquiry is never final, some explanations of the past are clearly more justifiable than others. Thus, history in a disciplinary form connects to Future 3, not Future 2, where 'knowledge depends on the knower' (Harris \& Ormond, 2019).

Some observation studies of history teaching have been conducted in Western countries during recent decades (Cuban, 2016; Goodlad, 1984; Husbands et al., 2003; Nokes, 2010; Saye et al, 2018). Most of these studies support the assumption that history teaching has followed the heritage approach. Teacher-centred methods and the memorization of a given narrative have dominated despite efforts to change history 
education. Cuban (2016) estimates that a relatively small minority of US history teachers aim to promote historical thinking in their classrooms. Nokes (2010) observes that the texts teachers use in their lessons rarely promote historical literacy. These results are supported indirectly by student-learning and teacher-thinking outcomes (Rantala, 2012; Reisman, 2012; Wineburg, 2001), which indicate that school history is often learned and understood in a traditional way.

An exception may be Britain, where the Schools Council History Project in the 1970s led to re-thinking the purpose and nature of school history (Seixas, 2017;

Shemilt, 1980). British scholars report that, at least to some degree, the pedagogy seems to have become more disciplinary (Husbands et al., 2003; Counsell, 2011; Harris \& Ormond, 2019) and that teachers resist reverting to the single narrative approach (Smith, 2019). Harris and Ormond (2019) conclude that, in England, about half of the schools in their sample used enquiry questions for sequencing content. Others used topic headings, which is the traditional way to organize lessons.

As noted, the pedagogical aspects of powerful knowledge are less developed than its knowledge theorization (McPhail \& Rata, 2018). Thus, before introducing our study in more detail, we briefly consider some guidelines for disciplinary history teaching that could support producing powerful knowledge.

\section{Towards a Future 3 pedagogy}

While acknowledging the strengths of disciplinary knowledge, McPhail \& Rata (2018) also consider the evident pedagogical challenges of this approach, namely that abstract concepts are difficult for students to grasp. Acquiring disciplinary knowledge requires the development of a pedagogy that is epistemically structured, motivating and engaging (McPhail \& Rata, 2018, p. 72). 
Following Durkheim and Vygotsky, Young and Muller (2014) define knowledge as something that we need in order to understand the world and to change it. At school, a learner's everyday concepts should be extended and transformed through pedagogy. Thereafter, the process should be reversed: learners draw on their newly acquired theoretical concepts to re-engage with and transform their everyday concepts. After the teaching and learning process, students would ideally be able to examine the world in a context-independent way (McPhail \& Rata, 2018). When applied to history, this could mean working with national contexts or with popular culture in order to be able to see them from wider perspectives through historical concepts and investigations.

History educators seem to agree that working with primary sources should be a starting point for disciplinary pedagogy. Seixas (2017) builds a synthesis of British, German and North American models of historical thinking. All traditions acknowledge the importance of doing history. Fogo (2014) used a Delphi survey to construct nine core practices for history teaching. The practices rated highest by North American scholars and experienced teachers included 'select and adapt historical sources' and 'model and support historical writing', while the lowest-rated practice in the list was 'explain and link historical content'.

In general, McPhail \& Rata (2018) suggest that successful powerful knowledge pedagogy would need to include direct but motivating instruction by the teacher, while noting that having a teacher as an instructor does not imply rote learning. Their argument, that abstract knowledge must be taught because it is not available from experience, seems well grounded. However, to avoid confusion with Future 1 and 2 pedagogies, we propose that teacher-centred and teacher-led pedagogy should be understood as two separate concepts with different meanings. Further, we suggest separating the idea of teacher as facilitator from both of the above-mentioned terms. 
While the teacher-as-facilitator approach may not help students to go beyond everyday knowledge (Future 2), a teacher-centred approach, namely lecturing, may feel meaningless for students (Future 1). Although studies of teaching for historical literacy do not straightforward disapprove of lecturing, they stress that students need time and space to make their own interpretations (Downey \& Long, 2016). This may not be achieved if there is too much of a focus on the teacher or on transmitting facts and ready-made interpretations.

On the other hand, learning historical investigation requires constant and efficient practice. What makes the inquiry approach even more challenging for teachers is the fact that students may still answer questions without relying on the sources (Barton, 1997; VanSledright, 2002). Since the ability to investigate the past in a disciplinary way is not available from experience, it is important for the teacher to model historical thinking and guide the students (Beck, 2014; Fogo, 2014).

\section{About the study}

\section{The research project}

Our data were drawn from a four-year research project entitled 'Engaging in disciplinary thinking: historical literacy practices in Finnish general upper secondary schools' (2016-2020). During the academic year 2018-2019, we conducted an observation study in which a total of nine upper secondary history teachers and nine primary school teachers were observed. One of the researchers observed each upper secondary teacher five consecutive times ( $5 \times 75$ minutes), and the other each primary school teacher's history lessons eight consecutive times ( 8 x 45 minutes). For the majority of the lessons, only one researcher was present, but at least once in each 
teacher's case both researchers observed the lesson together. In addition, four independent trained observers visited the classrooms. The teachers in the study were chosen through recommendations by administrators, teachers and researchers.

We took notes on questions, conversations and general interaction in the classroom. We collected assignments, learning materials and tests that the teachers used during the observation period. The lessons were not recorded on video or audio tapes. After the observation period, we interviewed each teacher. In addition to acquiring an insight into the teachers' pedagogical and disciplinary thinking, our aim was to see whether the teachers experienced the observed lessons as representative in relation to the whole school year. During the lessons, we sat at the back of the classrooms. Occasionally we communicated briefly with the teachers or the students, but did not take part in the teaching. The results of the broader data are to be published elsewhere.

\section{The case study}

The case study presented in this paper is based on an in-depth analysis of two upper secondary school teachers'́ classroom practices. Examples of promoting historical literacy are rare in our overall observation data. The criterion for selecting these cases was to introduce history lessons where, according to our interpretation, powerful knowledge was promoted. Both of our cases include a lesson where two observers were present.

The teachers described in this paper work in upper secondary schools in the Helsinki region. Both of the schools can be characterized as average. They have modern school buildings with adequate learning technology and well-organized surroundings. Students were either 16 or 17 years old. Peter's classes were slightly more monocultural than Mary's. 


\section{The context: Finnish schooling, teachers and the national core curriculum}

The Pisa results for 15-year-olds have attracted attention to Finland's education system in the past two decades. Although the Finnish Pisa results have fallen in recent years, Finland is still among the best-performing countries (Vettenranta et al., 2016). Attitudes towards education are fairly positive. Finnish teachers are satisfied with their work and working conditions in general (Finnish National Agency for Education, 2019).

Compared to most OECD countries, Finnish teachers have considerable autonomy. They are expected to follow the national core curriculum and participate in creating the local curriculum at the municipal and the school level. However, local curricula do not give direct instructions. Teachers decide how to sequence the course content, choose the learning materials (apart from the textbooks) and plan learning activities and assessment independently. Subject teachers study their subject as their major (mathematics, history, etc.) and are oriented to teach in secondary schools and upper-elementary schools. In order to become qualified teachers, students must undertake pedagogical studies in the faculty of education. Studies include teaching practice periods at university training schools (Puustinen, Säntti, Koski \& Tammi, 2018). Permanent teaching positions require a master's degree.

The national core curriculum for general upper secondary education connects knowledge production and critical thinking to the teaching of disciplinary literacies. Specific targets for history include both substantive and procedural knowledge. History teachers are expected to teach historical thinking skills, second-order concepts and historical empathy, for example (Finnish National Agency for Education, 2015). Even though disciplinary history has been emphasized in the national core curriculum since the 1990s, the shift seems to be slow. Research suggests that students' competence to work with historical evidence is weak in relation to curricular aims (Rantala, 2012; 
Rantala \& van den Berg, 2015). Most teachers support disciplinary aims when surveyed (Rantala \& Ouakrim-Soivio, 2018), but this may not reflect what actually happens in classrooms.

Finnish upper secondary school covers a three-year educational programme that consists of 75 courses. There are three compulsory and three optional history courses. The same teachers teach all six history courses as well as at least one other subject, which is usually social sciences (civics, economics, law). Students can organize their timetable by registering themselves for available courses. For teachers, this means that the class they are teaching is different for every course, and that some students base their course choices on the teacher's reputation. In order to graduate, students have to pass the matriculation examination (https://www.ylioppilastutkinto.fi/en/matriculationexamination).

\section{Cases and interpretation}

\section{Case 1. The independence of Finland as separatism}

Peter taught a course entitled 'The history of independent Finland', which deals with the political and societal history of Finland from the 19th century to the present day. As the name of the course implies, it is tempting to reproduce the narrative as related by nationalistic historiography. In this narrative, 'liberation' from Russia was described as the pre-ordained fulfilment of the national awakening (Meinander, 2013). Peter, however, led students down a different path. The following description is from two consecutive lessons.

Between 1809 and 1917, the area known as Finland today was an autonomous part of the Russian empire. At the end of the 19th century, Russia began governmental reforms, aimed at combining the administrationally divided empire. This so-called 
Russification significantly strained the relationship between Finland and St. Petersburg. The situation became tense when Tsar Nicholas II signed a manifesto in February 1899 stipulating that Finland was subject to the laws of the empire (Meinander, 2013).

Peter asked the students to refer to an assignment they had completed in the previous lesson. The assignment consisted of a link to the text of the manifesto and three questions, which focused on the style and message of the text and the justification for the actions that the manifesto stipulated. During the discussion that ensued, the students noted how the core message of the manifesto was hidden in its formal style and how the text praised the tsar but simultaneously conveyed a threatening tone. Peter pointed out the hidden message and asked whether it had been intentional and, if so, why? The students reasoned that by adopting an indirect approach, Finns would not gain that bad an impression of the manifesto. They based their interpretation on the text and noted that the manifesto aimed to present how being subject to Russia would be beneficial for Finland as well as the whole empire, and implied that Russia would take care of its autonomous grand duchy. When pondering the intentions of the Russian government, one student suggested that the manifesto may not have been intended to create a threatening atmosphere, as this could have generated a nationalistic and separatist counter-reaction from the Finns.

Before the lesson ended, Peter pointed out the alternative concepts used to describe the events in Finland at the beginning of the 20th century. For many contemporaries, the Tsar's action constituted oppression. This was the term adopted by nationalistic historiography. Peter explained how different terms conveyed different perspectives on the same historical period. He discussed how, from the Tsar's point of view, the manifesto was intended to prepare people for future actions that were likely to generate further negative reactions. 
At the beginning of the next lesson, Peter continued with the perspectives and concepts of the Russification period. In 1904, a Finnish nationalist, Eugen Schauman, assassinated Nikolai Bobrikov, who was the then Governor-General of Finland and who symbolized the oppression for many Finnish activists. The discussion became animated when a student analyzed the perspectives and interpretations: a later interpretation was that by assassinating Bobrikov, Schaumann sacrificed himself on behalf of the independence of Finland. However, for contemporaries, the assassination represented nothing more than the resistance of oppression (Meinander, 2013). Clearly delighted, Peter pressed on by asking what the Russians probably thought about the assassination and Schauman, to which students were quick to reply 'a fanatic, a terrorist'. Peter reacted with a nod and a conclusion about how important it was to recognize perspectives and that today a political murder would probably be viewed as terrorism.

As always, it is possible to find incidents that Peter could have handled differently. For example, the written assignment about the manifesto could have more explicitly guided students to analyze both the text and the context of the manifesto. In this case, the latter was done during the oral discussion. Both lessons mainly comprised teacher-led class discussions and explanation by the teacher which were related to the earlier assignment. Students had only two brief opportunities to re-develop their ideas either own their own or in small groups. In addition, Peter's decision to focus on perspectives and concepts neglected a more analytical approach to historical narratives and the production of historical knowledge. Nevertheless, Peter's lessons offer us one example of how a teacher can lead students to consider local or nationalistic perspectives from wider angles

\section{Case 2. The Holocaust}

Mary taught a course called 'International politics', which focused on this topic from 
the second half of the 19th century both in Europe and globally. Topics include imperialism, the World Wars, the Holocaust, the Cold War, and finally the political situation of recent years.

As an introduction to World War II, and perhaps as a motivational activity, Mary played Hitler's Head2head interview from the internet (activehistory.co.uk). The site has an animated Hitler head, which can answer questions. Mary instructed students to come up with questions, which were then presented to the website. After a while, the atmosphere in the whole class became tense. A student on the back row asked whether six millions victims [of the Holocaust] was too high a figure, and whether the number may have included people who died or went missing for other reasons. At this moment, Mary seemed to freeze. Nevertheless, after a few seconds she calmly stated that based on her understanding, six million was the correct figure. Mary immediately changed the subject. Another student on the back row then remarked in an ironic tone that one should not ask those kinds of questions if one did not want to be labelled.

After a few minutes, Mary returned to the topic. This time she noted that Holocaust deniers are driven by ideological motives, but did not elaborate on or justify her statement. As researchers, we could not help thinking that an opportunity to discuss the nature of historical knowledge and the (political) use of history had been lost. As it turned out, however, we were too hasty in our assumptions. After the next lesson, Mary continued dealing with the Holocaust.

Referring to the previous discussion about the victims of the Holocaust, Mary displayed a slide with information about German archives and civil registries, which constitute the evidential basis for knowledge about the number of victims. She explained that much information is available, even though it is also known that the Nazis attempted to destroy the archives. Mary continued with a question: Why were the 
Jews persecuted? Before discussing the issue in the whole class, students were given a moment to confer in small groups. During the class discussion, students brought up ideas such as social Darwinism, the stab-in-the-back myth, and the long tradition of anti-Semitism since the Middle Ages. Mary nodded and provided some details. She then displayed a slide with three different explanations: one given by Hitler, one drawn from historiography, and one provided by a social psychologist. The latter two led students from a single case to a more universal frame. Using concepts like segregation and xenophobia, Mary guided students to make generalizations.

Finally, Mary tackled the issue of Holocaust denial, displaying some of the most common formulations of the claim. She noted that historical evidence does not support any of the claims and countered them one by one. To demonstrate the significance of the Holocaust in the present day, she used a cartoon in which a bulldozer marked with a Star of David is building a wall around Jerusalem. An image of the Auschwitz-Birkenau concentration camp is superimposed on the concrete elements that form the wall (http://jcpa.org/article/anti-semitic-cartoons-on-progressive-blogs/). Students quickly recognized and interpreted the context of the cartoon, namely how the history of the Holocaust is used to criticize the actions of the state of Israel.

Mary's case represents an exemplary ability to tackle a challenging issue that came up during the course. In an interview after the observation period, Mary explained that she had modified her course plan in order to focus on the perturbing issue brought up by the student. However, an evident shortcoming during her lessons was the sense of constantly being a hurry. In our view, rushing ahead seems to be based on pressure to deal with all of the topics included in the national curriculum, and hence the need to cover everything that is included in the textbooks. 


\section{Analysis of the cases}

The two cases discussed above are anomalies of sorts in our larger observation data. Peter and Mary aimed to do more than merely transmit substantive knowledge. All of the teachers in our data made connections between the historical content and the present day. Nonetheless, there were no systematic attempts to unpack everyday knowledge that students encounter from historical culture, for example, or to analyze alternative narratives or the use of history. In this sense, Peter and Mary were unique in their promotion of disciplinary understanding.

In other classrooms, we observed how the history of Finland was presented as a single narrative without considering the interpretative nature of historical knowledge. In one case, a lecture-based lesson of the Russification period reproduced the heritagehistory story with detailed facts about Finnish resistance. In contrast, the way Peter unpacked the nationalistic narrative and promoted multi-perspective thinking demonstrated how to go beyond everyday history in a way that is more familiar to learners in time and space (Bertram, 2019).

The evident connection between interpretations of history and the contemporary world have led some scholars to draw the critical conclusion that history cannot be separated from everyday knowledge (Yates, 2017; Yates, 2018; see also Muller \& Young, 2019). Based on Case 1, we argue that some of the critical views might bypass the nature of everyday historical knowledge. As the heritage history that students learn from every day varies according to cultural and national contexts (e.g. Barton, 2001), the interpretations and perspectives that go beyond heritage are different as well. As Nordgren (2017) puts it, context-specific presumptions about other nationalities or cultures can be re-evaluated with conceptual tools. We suggest that compared to 
physics, for example, there are a considerable number of variations in everyday historical knowledge.

Developing understanding, which Parkes (2011) calls a historiographic gaze, requires substantive knowledge, which is dependent on the cultural context (see also Thorp, 2014). Following Lee (2007), we argue that disciplinary school history requires an intact narrative. In other words, the substantive knowledge is always present, but it varies from country to country. In addition, it should also be taken into account when each historical narrative was created. Although there are different 'everydays' to go beyond depending on the country and culture, it is still possible to form powerful knowledge in school history as long as the narratives remain intact. Disciplinary practices, in turn, can be seen as universal.

Mary's case illustrates the importance of grasping the process of historical knowledge production. Nokes (2013) describes how children think that the work of historians is to find facts in Wikipedia. If this view is shared among adults, it is easy to understand why denying the Holocaust and other such theories gain ground. Coming back to the Orwellian dystopia we started with, historical powerful knowledge should therefore provide disciplinary tools for unpacking heritage narratives in order to understand how history is used to build identities and to support present-day aims (Nordgren, 2017). This resembles the German tradition of historical consciousness, which aimed at understanding the interaction between interpretations of the past, perceptions of the present, and expectations towards the future (Bracke et al., 2014, cited in Seixas, 2017).

In the German tradition, learning to engage with history is seen as a means of historical sense-making (Seixas, 2017). Similarly, historical literacy abilities can be seen as essential for gaining powerful knowledge, and not only as an aim per se. 
Together with its evident merits, Mary's case also demonstrates why implementing practices that promote powerful knowledge is difficult. The students did not get the chance to investigate the evidence about the victims of the Holocaust for themselves. When they were supposed to form their own interpretations, Mary quickly drew the discussion to a close. Most of the time she was lecturing. Finally, the sourcing (Wineburg, 1991) of the cartoon that Mary used to illustrate how the history of the Holocaust is exploited today was incomplete. Mary noted that the cartoon had been drawn by an Iranian artist. What did not come up, however, was that it was subsequently used on an Israeli webpage as an example of anti-Semitic cartoons.

The short discussions between students left us, as observers, wondering whether the students had been given enough time to make their own interpretations before Mary hurried to answer the questions herself. Clearly Mary, like other teachers in our data, was under pressure to teach all of the substantive knowledge indicated in the national core curriculum and the textbook she used. If expected to teach a large quantity of detailed substantive knowledge in a short time, as Finnish upper secondary teachers are expected to do, they tend to fulfil this requirement and bypass procedural knowledge. This tendency seems to suggest that history is understood as heritage, namely that there is no strong epistemic and pedagogical understanding of disciplinary history.

Mary's case resonates with earlier research (Beck, 2014; Cuban, 2016; Westhoff, 2009). For example, Hicks et al. (2004) report that 82 per cent of the 158 teachers in their study requested students to select from primary sources the key individuals, events or ideas that frame the nationalistic story. As Beck (2014) notes, teachers may 'employ primary sources as gimmicks in an otherwise lecture-driven course or use them as an arbiter of dispute when asking interpretative questions'. Without epistemic understanding, primary material can be used as a visual element, 
ornaments in a slideshow, or offered as evidence of a ready-made interpretation. Therefore, in addition to using primary sources, teachers need to know how to use them. The findings of Hicks et al. (2004) address the risk of reducing literacy activities to Future 1 pedagogy. An evident response is to increase student-centred activities. This, however, is a critical situation where the epistemological understanding of the teacher comes into play. For example, the aim of a discussion should not be the discussion itself. There is little value in repeating everyday knowledge without new conceptual tools. Instead, learning to make sense of everyday knowledge by using disciplinary thinking would lead to new ways of thinking. Duhaylongsod et al. (2015) argue on behalf of classroom discussions when encouraging students towards disciplinary literacy. They note that discussions promote perspective-taking, academic language use and complex reasoning (see also LaRusso et al., 2015), all of which are important aspects of powerful knowledge. In addition, they suggest that discussion helps students learn more demanding moves in the discipline of history and that classroom discussion makes historical content engaging.

To conclude, we see pedagogy that supports powerful knowledge as a teacherled process, where students learn to think disciplinarily and context-independently. When it comes to history, the teacher's task is to lead students to learn both substantive and procedural knowledge, as well as broaden their understanding by analyzing historical evidence and interpretations.

\section{Discussion}

Young and Muller (2014; 2019) propose two counterparts for powerful knowledge: everyday knowledge and the knowledge of the powerful. To be powerful, knowledge should encounter both of them and allow for alternatives to be envisaged. 
We have suggested that everyday knowledge in history may differ from country to country, as well as from the definition by Young and Muller (2014). For example, the study by Wineburg and colleagues (2007) indicates that a significant part of students' prior knowledge reflects ideas from collective memory and historical culture. In Finland, Ahonen (1998) studied the relationship between Finnish adolescents and history. In the interviews, the Finnish youth shared an image of a patriotic Finnish soldier, who never gave up in even in the most overpowering of situations. In addition to family memories, this image was derived from historical culture. While it is beyond the scope of this paper to empirically study everyday historical knowledge, it seems reasonable to approach everyday knowledge in history from this point of view. If the everyday knowledge in school history is understood in this way, then there is no need to 'shut out the influences coming from everyday world of politics and daily life' (Muller \& Young, 2019; see also Yates, 2018), because they are part of the everyday world that the subject of history should deal with.

Based on earlier research, we have also suggested that school history has often represented the knowledge of the powerful. In some cases, the knowledge of the powerful seems to be closely connected to everyday knowledge. This is particularly highlighted by national narratives that might exclude minorities or wider perspectives. Historiography has a long tradition of national views (e.g. Berger, 2017).

Powerful knowledge has often been used as a frame to address problems associated with Future 2-like skills-based learning (Morgan, Hordern, \& Hoadley, 2019). In Finland, as in many other Western countries, politicians, interest groups and some educational actors have demanded school curricula reforms. This discourse is closely connected to the criticism levelled at teacher-centred teaching. Since the teacher's role is essential for pedagogy that aims to promote powerful knowledge 
(McPhail \& Rata, 2018), we acknowledge the importance of highlighting the key role of the teacher in a way that separates teacher-led pedagogy from traditional Future 1 teaching, as well as from experience-based Future 2 pedagogy. This is particularly important when it comes to teaching history, which balances between a fixed narrative and 'anything goes' approaches.

By separating teacher-centred and teacher-led pedagogy, we wish to highlight that even though it is a teacher's duty to lead students beyond everyday knowledge with disciplinary tools, this does not imply that the teacher only transmits information. As Morgan et al. (2019) note, advocating Future 3 may either lapse back into Future 1, for example by over-emphasizing substantive knowledge, or be misunderstood as supporting a 'Hirsch-inspired version of Core Knowledge'. However, it is equally important to note that student-centred activities are not an answer per se. With a teacher-as-facilitator approach, we refer to situations that may look engaging but which ultimately do not support disciplinary learning. An example could be a history classroom where students discuss historical topics or evidence without sufficient substantive and procedural knowledge. Thus, the discussion is likely to reproduce students' everyday knowledge and strengthen presentism.

The two cases analyzed in this study illustrate some pedagogical practices that promote disciplinary history in classrooms. Both teachers aimed to unpack the political use of historical knowledge, which we see as perhaps the most important feature of powerful knowledge in school history. However, when we or other researchers have taken a broader view of classrooms, history has often appeared to be reduced to heritage (Cuban, 2016; 2003; Nokes, 2010; Saye et al., 2018). It is in the transformation process from discipline to classroom where the disciplinary approach seems to be lost. 
In order to understand this transformation, the distinction between curriculum and pedagogy as suggested by Young (2014b) does not seem meaningful (Gericke et al., 2018). As Gericke and colleagues (2018) remind us, teachers have to consider didactical questions such as why, what, for whom, and when. Teachers negotiate with the curriculum, tradition, and learning materials and frame them within the perspective of their own understanding of the subject and its purpose, as well as the abilities and interests of their students. Next, we briefly consider the challenges of transformation in the context of school history.

At a societal level, history as a school subject faces constant political pressure, which links to the continuous socialization aims addressed for school history. Smith (2019) discusses how a hegemonic history curriculum can produce a heritage approach either by selecting the content, or methodologically by not encouraging disciplinary thinking. The idea of hegemony connects to everyday thinking about history: it seems commonsensical that school history should focus on national history and that the curriculum should contain a single narrative of uncontested facts. Examples from Britain and the United States (Nash et al., 2000; Smith, 2019) among others illustrate the tensions that surround history curricula. The views of history educators may well go unheard if those with power strive to strengthen their narrative.

At an institutional and classroom level, transformation is closely connected to the curriculum, whether national or local, and the learning materials. In many countries, including Finland, the national curriculum contains plenty of substantive knowledge, which may overshadow the other aims of school history. Added to teachers' inadequate understanding of how to use primary sources in a disciplinary manner (Cuban, 2016; Hicks et al., 2004; Nokes 2010), the persistence of the heritage approach is only to be expected. 
One important, but perhaps less studied aspect of transformation is the epistemic grounding teachers obtain during their education. Research indicates that it is difficult for historians to articulate what separates history from other disciplines (Yates, 2017) and to describe what they actually do in their research work (Knupfer, 2009). In addition, teaching at university level has traditionally involved lecturing. As a result, historians may have never demonstrated to future teachers how they engage with history and what kind of epistemology their engagement is grounded in. As Sears (2014) argues, 'most student teachers have a strong cognitive frame that history teaching essentially involves the passing on of historical information'. Moreover, even though there are teachers who are familiar with the inquiry approach to history teaching, they may be reluctant to implement it (Hartzler-Miller, 2001). Some studies even suggest that teachers are reluctant to teach diverse historical interpretations, arguing that such an approach is morally ambiguous and therefore harmful (James, 2008; O'Boyle, 2004).

Teaching disciplinary knowledge is difficult because it disturbs the commonsensical understanding of history. Pressure from society, politicians or parents may push teachers towards a heritage style of teaching and lead to situations where teachers have a constant need to justify their pedagogical choices. Without a strong disciplinary backbone and clear pedagogical models experienced as students, it comes as no surprise that teachers struggle to create disciplinary pedagogy. In addition, despite abandoning the 19th-century views of nation-building, history is often researched and published in a nation-state frame. As Nordgren (2017) argues, going against the national frame demand a lot from teachers.

For teacher education, this means that it has to challenge the epistemological beliefs of many student teachers and the pressure of the surrounding society. For example, in Finland in recent decades, teacher education has developed from a 
prescriptive and practice-oriented model towards having a research-based orientation (Säntti, Puustinen \& Salminen, 2018). Students are encouraged to construct personal practical theories (Puustinen et al., 2018). This development resembles the shift from the Future 1 to the Future 2 curriculum described by Young and Muller (2010). Under the umbrella of research-based teacher education, pedagogical practices that promote powerful historical knowledge have to be a part of teachers' epistemological beliefs and didactical thinking because, unlike a Future 1-like prescriptive orientation, ready-made models are not given. Aiming for Future 3 would mean promoting pedagogical understanding based on the nature of history as a discipline and students' abilities and learning. Without a strong epistemological foundation, a novice teacher who usually works alone can lapse into traditional pedagogical methods (Lortie, 2002).

The teachers presented in this case study were strong personalities who had a clear view of how they wanted to teach history. Based on our observations, we interpret Mary and Peter as being keen to implement their pedagogical ideas, although this would require departing from what was customary. Still, both had to juggle the content demands laid out in the curriculum and disciplinary practices. Lack of time is a wellknown challenge for teachers (Lortie, 2002).

Therefore, in order to help and encourage more teachers to embrace more disciplinary practices when teaching history, trimming the substantive knowledge in national curricula would be beneficial. Naturally, we recognize that we are not the first to suggest this. It is not politically easy to shorten national narratives or remove them from the curricula, and a curriculum that is completely content-free may not be a reasonable aim (Harris \& Ormond, 2019).

Research suggests that strengthening disciplinary literacy abilities is particularly beneficial for those students whose own competence is insufficient for interpreting 
difficult texts (Hynd-Shanahan, 2013). Schleppegrell et al. (2008) argue that while the dense language of history texts can be a barrier to learning, it is precisely this language that students need to be able to read and write in order to be successful. In addition to providing tools for understanding difficult and abstract texts (Fang \& Coatoam 2013), promoting historical literacy seems to support the acquisition of more substantive knowledge (Reisman, 2012). Thus, considering the ethos of equality in Young's vision of powerful knowledge (e.g. Young \& Muller, 2010), supporting historical literacy would be especially beneficial for those who most need help in seeing beyond the knowledge of the powerful.

In this study, we have suggested that understanding the interpretative nature of history, and thus being able to grasp how interpretations of history are used to support present-day aims, is an essential part of powerful historical knowledge. We also posit that everyday knowledge in history may differ from the definition by Young and Muller (2014), and that in order to avoid misunderstandings in the discussion about Curriculum Futures, it could be beneficial to separate teacher-centred and teacher-led pedagogy. Finally, in order to help students truly envisage the alternatives and reject the Orwellian use of history, we suggest focusing more on pedagogy and the transformation processes. 


\section{References}

Ahonen, S. (1998). Historiaton sukupolvi? Historian vastaanotto ja historiallisen identiteetin rakentuminen 1990luvun nuorison keskuudessa [The No-History Generation? The Reception of History and the Construction of Historical Identity by Young People in the 1990's]. Helsinki: Suomen historiallinen seura [Finnish Historical Society].

Barton, K. (1997). “I just kinda know”: Elementary students' ideas about historical evidence. Theory and research in social education, 25(4), 407-430.

Barton, K. (2001). "You'd be wanting to know about the past": Social contexts of children's understanding in Northern Ireland and the USA. Comparative Education, 37, 89-106.

Beck, C. L. (2014). Can teacher education programs learn something from teacher professional development initiatives? In R. Samwell \& A. von Heyking (eds.), Becoming a history teacher. Sustaining practices in historical thinking and knowing (pp. 249-269). University of Toronto Press.

Berger, S. (2017). History writing and the constructions of national space: The long dominance of the national in modern European historiographies. In M. Carretero, S. Berger, \& M. Grever (eds.) Palgrave handbook of research in historical culture and education (pp.39-57). London: Palgrave Macmillan.

Bertram, C. (2019). What is powerful knowledge in school history? Learning from the South African and Rwandan school curriculum documents. The Curriculum Journal, 30(2), 125-143.

Biesta, G. (2009). Good education in an age of measurement: On the need to reconnect with the question of purpose in education. Educational Assessment, Evaluation and Accountability, 21, 33-46.

Counsell, C. (2011). Disciplinary knowledge for all, the secondary history curriculum and history teachers' achievement. The Curriculum Journal, 22(2), 201-225.

Cuban, L. (2016). Teaching history then and now: A story of stability and change in schools. Cambridge, MA: Harvard Education Press.

Downey, M.T., \& Long, K.A. (2016). Teaching for historical literacy. Building knowledge in the history classroom. New York: Routledge. 
Fang, Z. \& Coatoam, S. (2013). Disciplinary literacy: what you want to know about it. Journal of adolescent and adult literacy, 56(8), 627-632.

Finnish National Agency for Education (2015). National core curriculum for general upper secondary Eeducation. Helsinki: Finnish National Agency for Education.

Finnish National Agency for Education (2019). Kansainvälinen opetuksen ja oppimisen tutkimus TALIS 2018 [Teaching and Learning International Survey]. Helsinki: Finnish National Agency for Education.

Fogo, B. (2014). Core practices for teaching history: The results of a delphi panel survey, Theory \& Research in Social Education, 42(2), 151-196.

Gericke, N., Hudson, B., Olin-Scheller, C. and Stolare, M. (2018). Powerful knowledge, transformations and the need for empirical studies across school subjects. London Review of Education, 16(3): 428-444.

Goldman, R., Britt, M. A., Brown, W., Cribb, G., George, M., Greenleaf, C., Lee, C. D., Shanahan, C. \& Project READI (2016). Disciplinary literacies and learning to read for understanding: A conceptual framework for disciplinary literacy, Educational Psychologist, 51(2), 219-246.

Goodlad, J. I. (1984). A place called school: Prospects for the future. New York: McGraw-Hill.

Haenen, J., \& Schrijnemakers, H. (2000). Learning to teach historical concepts. Teaching History, 22, 29.

Harris, R. \& Ormond, B. (2019): Historical knowledge in a knowledge economy - what types of knowledge matter?, Educational Review, 71(5), 564-580.

Harris, R. \& Reynolds, R. (2018). Exploring teachers' curriculum decision making: insights from history education, Oxford Review of Education, 44(2), 139-155.

Hartzler-Miller, C. (2001). Making sense of "best practice" in history teaching. Theory and Research in Social Education 29(4), 672-695.

Hicks, D., Doolittle, P. \& Lee, J. (2004). Social studies teachers' use of classroombased and web-based historical sources. Theory and Research in Social Education 32, 213-247.

Husbands, C., Kitson, A. \& Pendry, A. (2003). Understanding history teaching. Teaching and learning about the past in secondary schools. Maidenhead: Open University Press.

Hynd-Shanahan, C. (2013). What does it take? The challenge of disciplinary literacy. Journal of adolescent and adult literacy, 57(2), 93-98. 
James, J. (2008). Teachers as protectors: Making sense of preservice teachers' resistance to interpretation in elementary history teaching. Theory and Research in Social Education 36(3), 172-205.

Kagan, D. M. (1992). Professional growth among preservice and beginning teachers. Review of Educational Research 62 (2), 129-16.

Knupfer, P. B. (2009). A new focus for the history professoriate. Professional development for history teachers as professional development for historians. In R. G. Ragland \& K. A. Woestman (eds.), The teaching American History Project. Lessons for history educators and historians (pp. 29-46). New York, NY: Routledge.

Lave, J. \& Wenger, E. (1991). Situated Learning. Legitimate peripheral participation. Cambridge: Cambridge University Press.

Lee, P. (2011). History education and historical literacy. In I. Davies (ed.), Debates in history teaching (pp. 63-72). London; New York: Routledge.

Levesque, S. (2008). Thinking historically: Educating students in the 21st century. Toronto: University of Toronto Press.

Lowenthal, D. (1998). The heritage crusade and the spoils of history. Cambridge: Cambridge University Press.

Maposa, M. \& Wasserman, J. (2009). Conceptualising historical literacy - a review of the literature. Yesterday \& Today, 4, 41-66.

McPhail, G. \& Rata, E. (2018). A theoretical model of curriculum design. "Powerful knowledge" and " 21 st century learning". In B. Barrett, U. Hoadley, \& J. Morgan (eds.), Knowledge, curriculum and equity: Social realist perspectives (pp. 6379). London: Routledge.

Meinander, H. (2013). A history of Finland. New York: Oxford University Press. Morgan, J., Hordern, J., \& Hoadley, U. (2019). On the politics and ambition of the 'turn': unpacking the relations between Future 1 and Future 3, The Curriculum Journal, 30(2), 105-124.

Muller, J. \& Young, M. (2019). Knowledge, power and powerful knowledge re-visited, The Curriculum Journal, 30(2), 196-214.

Nash, G. B., Crabtree, C. \& Dunn, R. E. (2000). History on trial: Culture wars and the teaching of the past. New York: Vintage Books.

Nokes, J. (2010). Observing literacy practices in history classrooms. Theory \& Research in Social Education, 38:4, 515-544. 
Nokes, J. (2013). Building students' historical literacies. Learning to read and reason with historical texts and evidence. New York: Routledge.

Nordgren, K. (2017). Powerful knowledge, intercultural learning and history education, Journal of Curriculum Studies, 49:5, 663-682.

Orwell, G. (1950). Nineteen eighty-four: A novel (Reset.). London: Secker \& Warbur.

O’Boyle, A. (2004). The changing identities of history teachers in an Irish school. Pedagogy, culture and society, 12(3), 415-431.

Puustinen, M., Säntti, J., Koski, A., \& Tammi, T. (2018). Teaching: A practical or research-based profession? Teacher candidates' approaches to research-based teacher education. Teaching and Teacher Education 74, 170-179.

Rantala, J. (2012). How Finnish adolescents understand history: Disciplinary thinking in history and its assessment among 16-year-old Finns. Education Sciences, 2(4), 193-207.

Rantala, J. \& Ouakrim-Soivio, N. (2018). Opettajien näkemyksiä historian opetussuunnitelmaperusteista [Teachers' views on history curriculum principles]. Ainedidaktiikka 2(2) (2018), 2-20.

Reisman, A. (2012). Reading like a historian: A document-based history curriculum intervention in urban high schools, Cognition and Instruction, 30:1, 86-112.

Ryle, G. (1945). Knowing how and knowing that: The presidential address. Proceedings of the Aristotelian Society 46, 212-225.

Sandwell, R. (2014). On historians and their audiences: An argument for teaching (and not just writing) history. In Ruth Sandwell \& Amy von Heyking (eds.), Becoming a history teacher. Sustaining practices in historical thinking and knowing. University of Toronto Press, 77-90, 81.

Saye, J. W., Stoddard, J.,Gerwin, D. M., Libresco, A. S. \& Maddox, L. E. (2018). Authentic pedagogy: examining intellectual challenge in social studies classrooms, Journal of Curriculum Studies, 50(6), 865-884.

Schleppegrell, M. J., Greer, S. \& Taylor, S. (2008). Literacy in history: Language and meaning. Australian Journal of Language and Literacy, 31(2), 174-187.

Sears, A. (2014). Moving from the periphery to the core: the possibilities for professional learning communities in history teacher education. In R. Samwell \& A. von Heyking (eds.), Becoming a history teacher. Sustaining practices in historical thinking and knowing (pp. 11-29). University of Toronto Press. 
Seixas, P. (2006). Benchmarks of historical thinking: A Framework for assessment in Canada. Centre for the study of historical consciousness.

Seixas, P. (2017). A model of historical thinking. Educational Philosophy and Theory, 49(6), 593-605.

Seixas, P. C., \& Morton, T. (2013). The big six historical thinking concepts. Toronto: Nelson Education.

Shemilt, D. (1980). History 13-16: Evaluation study. Edinburgh: Holmes McDougall.

Shulman, L. S. (1986). Those who understand: Knowledge growth in teaching. Educational Researcher, 15(2), 4-14.

Smith, J. (2019). Community and contestation: A Gramscian case study of teacher resistance. Journal of Curriculum Studies.

Säntti, J., Puustinen, M., \& Salminen, J. 2018 Theory and practice in Finnish teacher education: a rhetorical analysis of changing values from the 1960s to the present day. Teachers and Teaching, 24(1), 5-21.

Thorp, R. (2014). Towards an epistemological theory of historical consciousness. Historical Encounters: A journal of historical consciousness, historical cultures, and history education, 1(1), 20-31.

VanSledright, B. (2002). In search of America's past: Learning to read history in elementary school. New York: Teachers College Press.

Vettenranta, J., Välijärvi, J., Ahonen, A., Hautamäki, J., Hiltunen, J., Leino, K., et al. (2016). Pisa - ensituloksia. Huipulla pudotuksesta huolimatta [Pisa - first results. At the top despite the drop]. Helsinki, Finland: Ministry of Education and Culture.

Wineburg, S. (1991). Historical problem solving: A study of the cognitive processes used in the evaluation of documentary and pictorial evidence. Journal of Educational Psychology 83(1), 73-87.

Wineburg, S. (2001). Historical thinking and other unnatural acts. Charting the future of teaching the past. Philadelphia, PA: Temple University Press.

Wineburg, S., Mosborg, S., Porat, D., \& Duncan, A. (2007). Common belief and the cultural curriculum: An intergenerational study of historical consciousness. American Educational Research Journal 44(1), 40-76.

Westhoff, L. M. (2009). Lost in translation. The use of primary sources in teaching history. In R. G. Ragland \& K. A. Woestman (eds.), The teaching American 
History Project. Lessons for history educators and historians (pp. 62-77). New York, NY: Routledge.

Yates, L. (2017). Schools, universities and history in the world of twenty-first century skills: The end of knowledge as we know it?, History of Education Review 46(1), 2-14.

Yates, L. (2018). History as knowledge: Humanities challenges for a knowledge-based curriculum. In B. Barrett, U. Hoadley, \& J. Morgan (eds.), Knowledge, curriculum and equity: Social realist perspectives (pp. 41-60). London: Routledge.

Young, M. (2009). Education, globalisation and the 'voice of knowledge'. Journal of Education and Work, 22(3), 193-204.

Young, M. F. D., \& Muller, J. (2010). Three educational scenarios for the future: Lessons from the sociology of knowledge. European Journal of Education, 45(1), 11-27.

Young, M. (2014a). Knowledge, curriculum and the future school. In Young, M., Lambert, D., With Roberts, C., \& Roberts, M. (2014). Knowledge and the future school: Curriculum and social justice (pp. 9-40). London: Bloomsbury.

Young, M. (2014b). The progressive case for a subject based curriculum. In Young, M., Lambert, D., With Roberts, C., \& Roberts, M. (2014). Knowledge and the future school: Curriculum and social justice (pp. 89-110). London: Bloomsbury.

Young, M. (2014c). Powerful knowledge as a curriculum principle. In Young, M., Lambert, D., With Roberts, C., \& Roberts, M. (2014). Knowledge and the future school: Curriculum and social justice (pp. 65-88). London: Bloomsbury. 
Table 1. Background of observed teachers

\begin{tabular}{|l|l|l|l|l|l|}
\hline Teacher & Years of & Education & Major & School & School size \\
& experienc & & ranking* & \\
\hline Peter & 12 & Master's & political & $50-$ & 460 \\
\hline Mary & 19 & degree & history & $100 / 387$ & \\
& & Master's & history & $100-$ & 1200 \\
& & degree & & $150 / 387$ & \\
\hline
\end{tabular}

*Based on position in national matriculation examination in 2019 (for more information, see https://www.ylioppilastutkinto.fi/en/). Note that there are no official school ranking lists in Finland. The listing presented here was produced by the Finnish public broadcasting company YLE. 